\title{
Ю.В. Деришев
}

\section{О СОВРЕМЕННОЙ ОТЕЧЕСТВЕННОЙ УГОЛОВНО- ПРОЦЕССУАЛЬНОЙ НАУКЕ В ОБЩЕМ И ОРГАНИЗАЦИИ СЛЕДСТВЕННОГО АППАРАТА В ЧАСТНОСТИ}

\author{
Учителю, коллеге и единомышленнику \\ профессору Анатолию Петровичу Гуляеву \\ посвящается \\ Грядущее на все изменит взгляд, \\ И странностям, на выдумки похожим, \\ Оглядываясь издали назад, \\ Когда-нибудь поверить мы не сможем. \\ Борис Пастернак
}

\begin{abstract}
Статья посвящена отдельным аспектам современного состояния отечественной уголовно-прочессуальной науки, а также оптимизачии функииональноправового и прочедурного построения уголовного досудебного производства. Критически анализируются отдельные позичии о месте следственного аппарата в государственном механизме, проблемы доследственного производства, острые вопросы взаимоотношений следователя с прокурором и ведомственным процессуальным руководителем. Предлагаются конкретные направления реформирования организачии и прочедур предварительного расследования 6 отечественном уголовном прочессе.

Ключевые слова: уголовное досудебное производство, организация и процедуры предварительного расследования, доследственное производство, следователь, прокурор, руководитель следственного органа.
\end{abstract}

События последних лет, связанные с «модернизацией процессуального цеха» отечественной уголовной юстиции, полностью подтверждают аксиому: ретроспектива российского уголовного процесса - это главным образом история противоречий его досудебного производства, которое чаще всего претерпевало различные трансформации, порождающие, в свою очередь, новые теоретические и практические проблемы [1. С. 41; 2. С. 99]. В связи с этим процессуальной науке скучать не приходилось ${ }^{1}$.

Взгляд в прошлое также свидетельствует, что наиболее существенные изменения в институтах отечественного уголовного досудебного производства

\footnotetext{
${ }^{1}$ Вместе с тем не могу не заметить (как член двух диссертационных советов), что отечественная уголовно-процессуальная наука в последние годы на фоне достаточно активной подготовки исследований по материальному уголовному праву больше отмалчивается, замерла в каком-то ожидании!
} 
обычно происходили в русле широкомасштабных судебных реформ, которые сами при этом органично вписывались в исторические, экономические, политические и нравственно самобытные сферы жизнесуществования России, являясь при этом, как правило, следствием глобальных исторических процессов, зачастую сопутствующих смене общественно-экономических формаций. Наибольший эффект государственно-правовых реформ в России достигался, когда они проводились при взвешенном учете прошлого опыта, лучших образцов зарубежного правового строительства, а также интересов и потребностей всех правовых сфер и институтов.

Общеизвестна и классическая формула политической подноготной подготовки и реализации государственных судебно-правовых реформ. В любом случае (!) это компромисс (своеобразный общественный договор) между концептуальной позицией правовой науки, предлагающей пути оптимизации нормативного регулирования тех или иных правоотношений, и администрацией государства, допускающей и выбирающей эти направления, определяющей при этом тактику и стратегию реформирования законодательства.

В современной России наблюдается несколько иная стратегия развития судебно-правовой реформы, в том числе и законодательства криминального блока. Известное «джентльменское соглашение» по реформированию права чаще всего заключается лишь между отдельными заинтересованными государственными ведомствами, которые «делят» УПК РФ на сферы влияния, а процессуальная наука остается далеко не всегда услышанной. И те наработки, которые были сделаны учеными-процессуалистами в последние годы, в большей степени законодателем не востребованы, что и послужило ключевой причиной возникновения коллизий и парадоксов уголовно-процессуального правоприменения первых десятилетий нового века. Если перефразировать известную пословицу, «лодка науки разбилась о быт», т.е. о ведомственные и научные амбиции!

Действительно, по мнению экспертов, довольно часто многочисленные и бессистемные изменения и дополнения законодательства являются продуктом притязаний отдельных заинтересованных и причастных к уголовному судопроизводству ведомств и служб [3. С. 43]. Чаще всего это бaнальный системный интерес - результативнее и менее затратно решать свои задачи, зачастую узковедомственные и порой сиюминутные ${ }^{1}$.

Нельзя не признать, что поиск выхода из этой ситуации продолжается, как очевидно и другое: и теория, и правоприменительная практика в ходе дискуссии об оптимизации отечественного уголовного судопроизводства пытаются получить в первую очередь определенные дивиденды для местнических потребностей или во благо обеспечения своих научных интересов.

В полной мере это коснулось и проблемы организации следственного аппарата страны. При этом можно констатировать, что все идеи по его мо-

\footnotetext{
${ }^{1}$ Яркий пример этому - современное состояние стадии возбуждения уголовного дела доследственного производства, которое серьезно лихорадит по причине ведомственного вмешательства в его регулирование, о чем речь пойдет ниже.
} 
дернизации сосредоточились на трех основных направлениях. Два из них предложены еще авторами Концепции судебной реформы, выступающими за единый следственный аппарат: либо создание независимой Федеральной службы расследования, либо учреждение (точнее, реанимация) института следственных судей (судебных следователей) [4. С. 67]. Третья позиция предусматривает полную ликвидацию предварительного следствия с его заменой аналогом германского «прокурорского или полицейского расследования», что, естественно, освобождает государство от решения проблемы «единого следственного аппарата».

Как известно, государство выбрало вариант с созданием Следственного комитета Российской Федерации. Новому ведомству необходимо было занять «свое» место в правоохранительной системе государства. Достаточно плодотворно поработала на авторитет молодой бюрократии ведомственная наука, что абсолютно естественно. Вместе с тем в своих достаточно аргументированных выводах коллеги порой не смогли уйти от крайнего радикализма (даже большевизма) и безапелляционности. Так, именно благодаря созданию и деятельности Следственного комитета РФ «сегодня предварительное следствие в России переживает свой ренессанс. Впервые не только образуются самостоятельные следственные органы, возникают новые субъекты следственной деятельности (следователь-криминалист), но и происходит также формирование науки и системы высшего образования, заточенной на потребности следственной практики. Из придатка какого-либо ведомства следствие трансформируется в самостоятельный орган государственной власти, а сама следственная деятельность - в полноценную институционально и юридически завершенную операционную систему. С образованием Следственного комитета полновесно реализуется замысел Петра Великого, воплощенный в созданных им 300 лет назад майорских следственных канцеляриях. В деятельности Следственного комитета государство российское обрело дополнительную мощную опору, а российское общество - ту силу, которая способна восстановить самый острый дефицит в нашем обществе - дефицит социальной справедливости. "Великая” эпоха всевластия прокурора сменяется новой эпохой - эпохой сильного следствия. Она, безусловно, изменит, да и сейчас уже изменяет весь облик и содержание уголовного судопроизводства. Есть все основания надеяться, что тот ренессанс, который переживает сегодня институт предварительного следствия, потянет за собой как цепную реакцию также и ренессанс всей системы отечественного судопроизводства. И, безусловно, не сотрется из истории вклад юристов - ученых и практиков, приблизивших наступление этой новой эпохи» [5. С. 69].

И далее: «Установившаяся прокурорско-полицейская модель организации предварительного следствия просуществовала в различных комбинациях вплоть до 2011 г. и прекратила свое существование с образованием Следственного комитета Российской Федерации. С этой даты следует говорить не о закате, а, наоборот, о возрождении Великой эпохи предварительного следствия» [6. С. 71]. 
Наконец, «сегодня следует констатировать, что в условиях нынешней парадигмы уголовного процесса альтернативы Следственному комитету нет» [7. С. 16]. Ни много ни мало!

Вполне очевидной, по крайней мере для автора данной статьи, остается идея сохранения в современной российской государственности сильной и независимой следственной власти, в чем с представителями научных учреждений Следственного комитета РФ нельзя не согласиться. Принципиальным остается вопрос о ее организации.

На этом фоне достаточно заметна иная, кардинально противоположная и не менее радикальная позиция представителя Европейского университета в Санкт-Петербурге М.Л. Позднякова, который твердо убежден, что именно Следственный комитет РФ - «Главное препятствие на пути реформы российского уголовного судопроизводства. Досудебное производство по уголовным делам должно быть решительно десоветизировано, чтобы отвечать стандартам развитых - европейских правопорядков» [8. С. 20], так как «ничего хорошего из проекта под названием СКР, несмотря на мощное пропагандистское обеспечение, не вышло и не выйдет» [Там же. С. 21]. При этом он изобличает «не вполне бескорыстных реформаторов из СКР» в «ползучей контрреформе в сфере уголовного судопроизводства», с чем «сторонникам демократии и свободы (с которыми, как представляется, ассоциирует себя автор как представитель Европейского университета. - Ю.Д.)... нельзя мириться» [Там же. С. 21]. Единственно верной и непогрешимой представлена «Концепция комплексной организационно-управленческой реформы правоохранительных органов», разработанная представляемым автором вузом. «Это путь к евроинтеграции, и “иного нет у нас пути”» [Там же. С. 22]. Остается добавить: «...в Европе остановка!»

Вместе с тем автор вольно или невольно признает, что «полицейское дознание» как форма предварительного расследования существует в России уже достаточно давно. Особенно очевидным это стало после принятия УПК РФ. Действительно, можно согласиться, что современные следователипреследователи (но не исследователи) - это «офицеры по расследованию» и что Следственный комитет РФ - это также «полицейское ведомство». Более того, вполне очевидно, что современная форма расследования в ее организации и есть полицейское дознание - более квалифицированное, осуществляемое так называемыми следователями, и менее квалифицированное, осуществляемое дознавателями. Фактически и юридически это произошло с передачей следственного аппарата в далеком 1928 г. в ведение прокуратуры - органа исполнительной ветви власти. Развитие это положение получило дальнейшим наделением полицейских ведомств функцией производства предварительного следствия.

По-видимому, не замечая этого, М.Л. Поздняков требует создать уже созданное «полицейское досудебное расследование» по аналогу институтов, существующих в «развитых правопорядках». Вместе с тем, сознавая, что у предварительного расследования, переданного «федеральной криминальной полиции», есть очень слабые места, например по расследованию 
сложных уголовных дел экономической направленности, автор предлагает создать подотчетную Государственной Думе РФ Федеральную службу по расследованию должностных преступлений, «которая должна прийти на смену нынешнему СКР» [8. С. 23]. При этом автор умалчивает, кто будет расследовать другие сложные и объемные дела: о катастрофах и пожарах, серийных маньяках, системном наркотрафике и т.п.? Справится ли с этим «нормальное», деформализованное, непроцессуальное «полицейское досудебное расследование» [Там же. С. 22]? Или после развала Следственного комитета придется еще что-то построить? Государству необходимо помнить подобные «эксперименты», когда был ликвидирован достаточно профессиональный следственный аппарат налоговой полиции, а позже службы Госнаркоконтроля. А создавать пришлось на пустом месте!

Еще одно заблуждение. Предлагая «просто... понять, что никакого отношения следственная власть к судебной власти не имеет, - подобное представление является пережитком следственной (советской) идеологии» [Там же. С. 23], автор игнорирует (либо подтверждает свою некомпетентность) историю и опыт государственного строительства не только России, но и обожаемой им Европы.

Идеи М.Л. Позднякова по известным причинам близки и его коллегам по Европейскому университету, которые на основе лишь социологических исследований приходят к безапелляционному, на их взгляд, выводу: «Юридикализация всего следствия поголовно - это сложный и совершенно ненужный процесс возведения полицейской работы в ранг работы почти судебной. Технические, рутинные (но необходимые в любом обществе) операции возводятся в ранг «применения закона» специально уполномоченным и квалифицированным лицом. Эта проблема хорошо видна и в чисто юридической дискуссии - догматически противопоставляются модели полицейского дознавателя (полиция) и следственного судьи (суд). По итогам эмпирических исследований мы можем сказать: противопоставлять тут нечего - в России благодаря эффектам институционального изоморфизма скорее следствие превратило суд в подобие полиции, чем суд вырастил между собой и полицией преграду в виде квалифицированных следователей» [9. С. 187-188].

Вполне очевидно, что если бы специалисты Европейского университета не замыкались на поставленной перед ними задаче «евроинтеграции во что бы то ни стало», они бы даже на основе тех же проведенных исследований пришли к однозначному выводу: все беды организации отечественного следственного аппарата в России как раз и связаны именно с его полицейской, но не судебной принадлежностью, с игнорированием его исторических корней.

Что касается страстного желания «наутро проснуться европейцем», то сторонникам «продвинутых правопорядков» следует прислушаться к позиции своего авторитетного земляка. Для этого необходимо только перебраться на другой берег Невы, к зданию старого Сената. Как считает В.Д. Зорькин, «мы... в слепом копировании западных либеральных стандартов удари- 
лись в крайности, дошли до радикаллиберализма. Прежде всего это касается уголовного и уголовно-процессуального законодательства» [10].

При этом справедливости ради следует признать, что данные побольшевистски революционные идеи евроинтеграции были предложены еще до провозглашения в стране «движения импортозамещения».

Уважаемый читатель! Перед вами два противоположных воззрения, которые, тем не менее, имеют общий фундамент: полное непринятие позиций инакомыслящих оппонентов. И это одна из основных методологических проблем современной науки уголовного процесса, особенно в части решения судьбы следственного аппарата государства. Поистине, как заметил главный редактор журнала «Уголовный процесс» И.Р. Рамазанов, на фоне ожесточенного неприятия отдельных позиций спорящие порой не слышат друг друга [11. С. 3].

В поисках необходимого консенсуса при определении оптимального построения предварительного расследования в стране обратимся к анализу ряда принципиальных правоприменительных и научных проблем уголовного досудебного производства.

Все более очевидным становится, что самое слабое место в современной организации предварительного следствия - это вопросы взаимоотношения следователя, его ведомственного процессуального руководителя и прокурора. Идея разделения функций расследования и прокурорского надзора за ним, казалось бы, реализована. Действительно, дореформенный прокурор исследователями представлялся как «змей о трех головах» (да простят этот образ уважаемые коллеги). Одна голова управляла прокуратурой, другая - «двигала» уголовное преследование, а третья осуществляла надзор за законностью данной деятельности. По вполне понятной причине (ведомственные показатели) все три головы постоянно входили в противостояние друг с другом, и прокурору в целом оставаться объективным было достаточно сложно.

С революцией 2007 г. и созданием самостоятельного следственного ведомства, по мнению экспертов, в частности Л.В. Головко, «отечественная система предварительного расследования, прежде базировавшаяся на чемто, быть может, и устаревших, но казавшихся еще прочными советских институциональных основах, не только не укрепилась, но, напротив, вступила в полосу турбулентности... Следователь самостоятельнее отнюдь не стал, да и надзор никто никуда не “отделил": большинство прежних полномочий прокурора просто-напросто перешли к руководителям следственного органа» в рамках процессуального ведомственного контроля... В результате «прокурорский надзор не "отделился", а почти вовсе исчез, став едва ли не эфемерным, тогда как прежние "надзорные" полномочия превратились в полномочия "контрольные", причем опять-таки в рамках одного ведомства (СК)». Таким образом, «соединение в одном ведомстве следственных и надзорных функций - это зло, а соединение в одном ведомстве следственных и контрольных функций - благо. Где логика?» [12. С. 44]. Как результат, прокурор «процессуальную власть значительно утратил, 
а следователь ее так и не приобрел, будучи к тому же абсолютно связан руководителем следственного органа [12. С. 45].

Логики действительно нет, это вполне очевидно и объективно! Поэтому в ответ снова лозунги и призывы. «Новый тип процесса раз и навсегда разводит следователя и прокурора в уголовном судопроизводстве так, что впредь эти процессуальные фигуры вообще не пересекаются. Никакая процессуальная логика тем самым, вопреки утверждению профессора Л.В. Головко, не убивается. Если что и убивается, так это стереотипы, ничего общего с логикой не имеющие. А логика только начинает выстраиваться» [6. С. 81].

Вместе с тем в это же время руководство Следственного комитета РФ предлагает принципиально рассмотреть дилемму: сохранить или ликвидировать процессуальный ведомственный контроль в деятельности ведомства [13. С. 38], что вполне откровенно свидетельствует о системном кризисе «социально-правовой идентичности» не следователя и прокурора, а руководителя следственного органа и его подчиненного [14. С. 14-19]. Вопрос, может ли быть в полной мере объективным и эффективным внутренний, «домашний», местнический самоконтроль, поставлен «ребром»!

Так, выступая за усиление и укрепление надзорной функции прокурора в целях минимизации обвинительного уклона, Л.А. Воскобитова констатирует, что, «несмотря на существенное усиление процессуальных полномочий руководителя следственного органа (ст. 39 УПК), пока не удалось существенно повысить качество расследования в российском уголовном судопроизводстве. Попытка перевести эту сложнейшую проблему в плоскость борьбы амбиций с перекладыванием ответственности за результат с одного органа на другой [15. С. 33-39] только препятствует ее решению» [16. С. 461].

По мнению Н.А. Колоколова, «законодателю не лишним будет вернуться к вопросу о достаточности прерогатив прокурора для осуществления полноценного надзора» [17. С. 16]. При этом автор выступает за «неоспоримое право прокурора поручать следователю собрать необходимые по делу доказательства», ибо «прокурор в целом отвечает за дело, а не следователь» [Там же. С. 28-29].

С данными позициями можно согласиться уже потому, что созданная в последние годы организация предварительного расследования в России все меньше напоминает классическое предварительное следствие, где офицеры по расследованию лишь по названию должности «следователи». Продолжает формироваться полицейское (даже не прокурорское) дознание, аналоги которому среди архетипов досудебного производства найти крайне трудно! Действительно, «с реформой 2007 г. советская модель предварительного расследования окончательно «расползлась», а новая создана не была» [12. С. 45].

Отлучение прокурора от надзора за предварительным расследованием далеко не единственное условие создания сильной следственной власти. Предварительное следствие не должно быть полицейским. Так, Л.В. Головко, изучая реформы уголовно-процессуального законодательства Республи- 
ки Казахстан, вынужден был констатировать, что Следственный комитет может быть только полицейским ведомством, что вполне очевидно доказали, «например, казахские реформы середины 1990-х гг.» [18. С. 10-13]. Действительно, парадокс! Следственный комитет есть, а предварительного следствия нет. Поистине феномен Чеширского кота: улыбка есть, а кота нет [19. С. 18-23].

Вместе с тем не могу не заметить, что автор этих строк много лет последовательно выступал против сохранения прокурорского надзора за предварительным следствием [20. С. 269-291], но при одном условии: предварительное следствие осуществляет судебный следователь, а полицейским дознанием должен руководить прокурор.

Как известно, 19 сентября 2018 г. группой депутатов в Государственную Думу Российской Федерации внесен проект федерального закона «О внесении изменений в Уголовно-процессуальный кодекс Российской Федерации (о расширении полномочий прокурора в досудебном судопроизводстве)». Решит ли он поставленные проблемы? Или это опять законотворчество по системе маятника: из крайности в крайность?

В одной из своих последних работ большой знаток «следственного дела», профессор А.П. Гуляев предложил концепцию реформирования предварительного расследования преступлений, «т.е. той самой деятельности, которая в значительной мере предопределяет качество осуществления такой важной государственной функции, как правосудие» [21. С. 2].

При этом мэтр отечественной уголовно-процессуальной науки, много лет исследовавший проблемы деятельности следователя, предложил решить десять концептуальных вопросов организационного, правового и нравственного характера. Выделим лишь ключевую идею функциональноправового построения уголовного досудебного производства. Это создание единого и самостоятельного государственного аппарата по осуществлению предварительного следствия, автономного от органов исполнительной ветви власти; обеспечение его организационной независимости в системе органов государственной власти, а также четкое законодательное определение правового статуса следователя, задач и функций органов предварительного следствия. При этом следователь должен в законе определяться как исследователь, но не преследователь (обвинитель) [Там же. С. 2-3].

Действительно, в современном отечественном уголовном процессе сохраняется перманентно актуальная потребность в оптимальном выборе процессуальной формы производства по уголовнылм делам, исходя из специфики и общественной значимости совершенного преступления, что не вызывает особых сомнений ни в теоретическом, ни в практическом плане.

В связи с этим юридическому сообществу предлагаются следующие наблюдения и соображения по оптимизации функционально-правового и процедурного построения уголовного досудебного производства России.

1. Доследственное производство как «реликт социалистической законности» [22. С. 34-36] продолжает мутировать. Это уже даже не «суррогат» расследования, как характеризовали данное производство эксперты в пе- 
риод действия УПК РСФСР. В современном отечественном уголовном процессе со всей очевидностью сформировалось самостоятельное, относительно квалифицированное производство по уголовному делу в форме предварительного расследования первого уровня, за которым идет собственно предварительное расследование (окончательного уровня), которое практически присваивает «знак качества» предыдущей деятельности. Действительно, внесенные в УПК РФ изменения, расширение полномочий дознавателей и следователей на стадии проверки сообщения о преступлении превратили ее в «квазирасследование», функционально подменяющее следующую за ней стадию» [23. С. 85-90].

Так, следователи Следственного комитета РФ, проверяя в год до 1 млн сообщений о происшествиях, возбуждают не более $17-18 \%$ уголовных дел. Высококвалифицированные специалисты фактически выполняют функции органов дознания, которые при этом продолжают профессионально деградировать. Серьезно деформируется и сам следственный аппарат, в связи с чем признано, что Следственный комитет переродился в «доследственный», и выхода из этого тупика не видно [24].

Эксперты определили стоимость одного уголовного дела в 248781 руб. (2012 г.) [25. С. 82]. Парадоксально, но эта цифра заметно возрастает как в случае ликвидации стадии возбуждения уголовного дела (как предлагает МВД России), так и в современной ситуации, когда фактически формируется два уголовных дела: в порядке доследственного производства, где следователи, заглядывая далеко вперед, пытаются определить судебную перспективу для разрешения уголовного дела, так как «система» запрещает прекращать возбужденные уголовные дела, и собственно при производстве «официальной части» предварительного расследования.

Действительно, «беспрецедентное разрастание доследственной проверки, имеющее своим следствием размывание границ между процессуальной и полицейской деятельностью, в значительной мере обусловлено нерешенностью вопроса о месте следственных органов в структуре государственной власти» [26. C. 15].

Необходимо признать, что уголовно-процессуальная наука выступает объективным и беспристрастным свидетелем тех теоретических трудностей, с которыми столкнулись советские, а затем российские процессуалисты в своих попытках аргументировать самостоятельный процессуальный характер рассматриваемой стадии уголовного судопроизводства.

Доводы за сохранение данной стадии вполне «традиционны»: «в кризисный период развития нашей страны отказываться от апробированных и проверенных многими десятилетиями институтов... нецелесообразно» [27. С. 69]. Вместе с тем данной стадии в подобном виде не знал ни русский, ни ранний советский, ни зарубежный уголовный процесс. От нее отказываются и государства постсоветского пространства (Грузия, Украина, Казахстан).

Очевидно и другое. «Незавершенность процесса отделения дознания от предварительного следствия в XIX в. и в советский период привело к извращению роли дознания. Деление предварительного расследования на 
дознание и предварительное следствие как на этапы досудебного производства было подменено его делением на дознание и следствие как самостоятельные формы расследования. Ликвидация дознания как способа проверки сообщения о преступлении привела к формированию новой формы проверки, получившей название доследственной» [26. С. 15].

В связи с этим в качестве de lega ferenda следует стадию возбуждения уголовного дела трансформировать ${ }^{1}$ в осуществляемое в рамках уголовнопроцессуального и административного законодательства полицейское дознание по проверке сообщений о противоправных действиях, выявлению преступлений и установлению оснований для начала предварительного расследования по уголовному делу, которое, в свою очередь, следует исчислять с момента принятия процессуального решения либо производства любого следственного действия, ограничивающих права и свободы участников уголовного судопроизводства, без необходимости вынесения какого-либо правоустанавливающего акта (так, согласно ст. 179 УПК Республики Казахстан началом досудебного расследования является регистрация заявления, сообщения об уголовном правонарушении в Едином реестре досудебных расследований либо первое неотложное следственное действие).

Представляется, что юридическим результатом данного производства необходимо рассматривать полицейский протокол, в котором делается вывод о наличии признаков преступления или иного правонарушения, и таким образом определяются движение документов о происшествии и дальнейший режим производства в рамках уголовного дела либо административного производства.

2. В рамках УПК РФ современный законодатель отказался от досудебного исследования обстоятельств совершенного преступления в пользу уголовного преследования (прокурорского или полицейского дознания), что повлекло за собой снижение качества досудебного производства, а это, при значительном повышении требований законодателя к стандартам доказывания (особенно при разрешении дела в суде с участием присяжных заседателей), привело к определенному разбалансированию всего уголовного судопроизводства. В связи с этим представляется, что перерождение предварительного следствия в «прокурорское дознание», а процессуально самостоятельного следователя - в ведомственного дознавателя, зависимого от процессуального (административного) руководителя (т.е. следователя только по форме и наименованию должности), стало следствием непонимания или сознательного игнорирования правовой природы и предназначения предварительного следствия - предварительного, т.е. досудебного исследования обстоятельств совершенного преступления.

Действительно, в современном отечественном уголовном процессе предварительное производство практически реализуется через функцию

\footnotetext{
${ }^{1}$ Но не ликвидировать, так как на пустом месте очень быстро и интенсивно растут чертополохи. По какой-то причине именно «ликвидаторскую» позицию порой приписывают автору данных строк не очень внимательные оппоненты.
} 
досудебного уголовного преследования, которое возникает при фактическом ограничении прав лица, вовлеченного в уголовно-процессуальные правоотношения в связи с установлением его причастности к совершенному преступлению, и заключается в осуществлении процессуальной подготовки и обосновании материально-правовой стороны уголовного иска к данному субъекту. Дифференциация процессуальной формы досудебного уголовного преследования предполагает наличие двух процедурных режимов: более квалифицированного производства, именуемого в УПК РФ предварительным следствием, и сокращенной досудебной подготовки материалов в форме дознания, что свидетельствует о формировании в российском уголовном процессе полицейского расследования (уголовного преследования) по германскому типу, но с отлучением прокурора от его руководства.

Предварительное расследование в России лишь в период с 1860 по 1928 г. развивалось на основе признания за ним юстициионных корней, т.е. рассматривалось в качестве функционала судебной власти. В остальное время, особенно с конца 20-х гг. прошлого столетия, данный правовой институт (и, по сути, досудебное производство в целом) все больше попадал в организационную и правовую зависимость от административных органов государства.

Вместе с тем очевидно, что судебная власть никогда не станет полностью независимой до тех пор, пока сохраняется источник влияния на объективность ее решений через открытое для внешних воздействий досудебное производство, организованное на принципах субординации и подчинения административным органам власти! Более того, по своей гносеологической, правовой, аксиологической и историко-генетической природе следственная власть является производной от власти судебной при полном совпадении их назначения, в связи с чем предварительное следствие есть функция юстиции, а следователь должен рассматриваться как ее представитель и находиться при судебном ведомстве. Именно принадлежность к судебной власти, целеполагание которой (установление истины) полностью совпадает с назначением предварительного следствия, не только обеспечивает процессуальную самостоятельность следователя, но и является предпосылкой вынесения законного, объективного и справедливого приговора. Возвращцение к институту судебного следователя будет являться важным юридическим, идеологическим, социально-политическим и организационно-техническим актом реформирования отечественного уголовного досудебного производства.

В связи с этим следственный аппарат должен быть организован при судебном ведомстве в качестве самостоятельного Следственного департамента Верховного Суда РФ и, соответственно, следственных департаментов судов субъектов Российской Федерации. При этом принадлежность следователя к судебной власти не только становится гарантией его процессуальной самостоятельности и независимости, но и создает объективные условия формирования состязательного досудебного производства. 
Любое иное построение следственного аппарата так или иначе ставит следователя в полную или частичную зависимость от исполнительной или законодательной власти, что, естественно, недопустимо. Как свидетельствует российский и зарубежный опыт построения досудебного производства, не только чертой, но и условием его демократичности выступает строго юстиционный институт предварительного (prima facie) судебного исследования обстоятельств совершенного преступления (это обеспечивает и его объективность). Именно предварительное досудебное исследование обстоятельств совершенного преступления является подлинной предпосылкой вынесения объективного, законного и справедливого приговора. Кроме того, очевидна прямая связь между обращением к институту судебного следователя и установлением консенсуса доверия между судебной и следственной властью в оперировании доказательствами, возможностью последней «вписаться» в менталитет русского человека, для которого одним из основных вопросов мировоззрения всегда оставался вопрос: «кто виноват?».

Прокурор в досудебном производстве должен выступать в разных ролях: при производстве предварительного следствия - исключительно как сторона обвинения, лишенная надзорных полномочий; в доследственном и сокращенном производствах - как процессуальный руководитель уголовного преследования, совмещающий функцию обвинения и надзора за законностью уголовно-процессуальной и оперативно-розыскной деятельности.

Разграничение функций разрешения дела по существу и осуществления судебного контроля за законностью и обоснованностью предварительного следствия обеспечивается введением относительно независимой от суда фигуры следственного судьи (при судебно-следственных палатах или судебно-следственных коллегиях), выполняющего самостоятельную судебно-контрольную функцию ${ }^{1}$.

Таким образом, понятием «предварительное расследование» должно охватываться, во-первых, производство органами, осуществляющими уголовное преследование (прокурором и подчиненными ему органами дознания), неотложных или первоначальных следственных действий либо сокращенного (ускоренного) производства и, во-вторых, производимое следователем предварительное следствие.

При этом основным критерием выбора режима предварительного расследования должно выступать наличие (или отсутствие) спора между сторонами при разрешении уголовно-правового конфликта (уголовного иска). В первом случае обязательно производство предварительного следствия (с элементами состязательности), а сокращенное производство допускается

\footnotetext{
${ }^{1}$ Как известно, во Франции, наряду со следственным судьей (судебным следователем), осуществлявшим как предварительное следствие, так и судебный контроль за расследованием, проводимым судебной полицией, в уголовный процесс введена должность судьи по свободам и заключению, которому по Закону от 15 июня 2000 г. перешла часть полномочий следственного судьи и который стал еще одним судебным органом, обеспечивающим законность предварительного следствия (право принятия решения о заключении под стражу принадлежит теперь только последнему).
} 
лишь при отсутствии подобной правовой коллизии. При этом необходимо обеспечить гибкость выбора режима досудебного производства, исходя из особенностей уголовного дела, и при дальнейшем законодательном поиске альтернатив уголовному преследованию.

Предварительное следствие как квалифицированная форма расследования должно осуществляться по преступлениям (как правило, тяжким и особо тяжким), требующим тщательного исследования обстоятельств криминального события и его последствий. Следует оптимально упростить досудебную подготовку материалов уголовного дела о преступлениях, не требующих предварительного следствия, а современную стадию возбуждения уголовного дела и дознание заменить «уголовным розыском в широком смысле» (полицейское дознание и сокращенное производство). Именно данная деятельность должна стать основой уголовного преследования (по подавляющему большинству преступлений), т.е. обвинительного производства, осуществляемого прокурором и руководимыми им органами дознания.

В заключение следует напомнить, что несколько лет назад государство уже просмотрело «момент истины». В 1987-1989 гг. решался вопрос о создании единого независимого следственного аппарата под эгидой МВД СССР. Проводившийся в связи с этим эксперимент подтвердил правильность и прогрессивность такого решения: главным его итогом явилось формирование фигуры следователя как процессуального руководителя расследованием. Статистика говорит сама за себя: если только число незаконных арестов в 1988 г. сократилось по стране на 2,4\%, то в экспериментальных следственных подразделениях - на 28,0\% [28. С. 250]. Следователи искренне приветствовали готовящуюся реформу и ждали ее быстрейшего воплощения в жизнь. Однако в феврале 1989 г. эксперимент внезапно волевым решением и без всякого на то объяснения был свернут, его результатам дана искаженная, не соответствующая действительности оценка, а практически полностью подготовленная реорганизация следствия безмотивно отвергнута ${ }^{1}$.

Началась кадровая лихорадка. Разочаровавшись в непоследовательности государственных шагов по реформированию следственного аппарата, его стали активно покидать профессионалы следственного дела. Кадровый коллапс наметился уже к середине 90-х гг. ХХ в., когда на следственные должности приходилось принимать людей со стороны. Вместе с тем 19701980-е гг. следует назвать «золотым веком» советского предварительного следствия. Это действительно была эпоха высокого профессионализма и культуры, стабильности и взаимопонимания, хотя и не без отдельных проблем. И это позиция не только автора этой статьи.

\footnotetext{
${ }^{1}$ Наиболее используемый аргумент тех лет против выделения следствия из МВД: нарушение взаимодействия служб. Еще один утопический продукт ведомственной, в данном случае милицейской науки, где игнорировалось одно, но главное противоречие руководитель (следователь) не может взаимодействовать с подчиненным (органом дознания), как не может взаимодействовать с ними также суд, прокурор. Здесь действуют принципы процессуального подчинения.
} 
Сейчас следственный аппарат страны также откровенно лихорадит. Сохраняются высокая степень неукомплектованности профессионального ядра, проблемы внешних и внутренних взаимоотношений, принципиальный вопрос об организации процессуального надзора за расследованием и др.

На фоне иных негативных процессов, происходящих в стране, угроза окончательной утраты профессионального предварительного расследования вполне очевидна. Действительно, наступил «момент истины», когда процессуальной науке уготована особая роль: освободившись от узковедомственных и сиюминутных амбиций, найти и предложить государству единственно верные шаги по оптимизации предварительного расследования.

Эффективная государственная уголовно-процессуальная политика обеспечивается формированием в рамках общей юридической доктрины собственной теоретической концепции, которая в качестве обязательных базовых положений должна отразить: объективную оценку сложившейся в современном российском обществе социальной, политической, экономической, духовной и правовой ситуации; реальные возможности права адекватно противостоять преступности; ключевые проблемы и противоречия развития социума и государства; стратегические и тактические цели и ориентиры дальнейшего развития законодательства; наиболее эффективные (оптимальные) средства и методы их достижения. При этом ее реализация носит не только юридический, но и политический, экономический и идеологический характер, в связи с чем следует признать, что современная внешняя уголовно-процессуальная политика российского государства (отвечающая за соответствие уголовно-процессуального законодательства международным стандартам и, соответственно, его оценку со стороны мирового юридического сообщества) имеет приоритетное значение по отношению к внутренней, разрабатывающей и реализующей меры правового характера для удовлетворения потребностей общества и государства на определенном этапе его развития в сфере контроля преступности).

В связи с этим не менее очевидно, что теоретической платформой для рассматриваемых выше компромиссов всегда выступало наличие единой napaduгмbl, не только принимаемой и разделяемой научным сообществом, но и объединяющей большинство его членов. Иными словами, внутри научного сообщества также нужен компромисс, более или менее единое видение собственной теоретической концепции, в частности процедурного и функционально-правового построения уголовного досудебного производства.

\section{Лuтература}

1. Смирнов А.В. Современные проблемы следственной власти в России // Уголовный процесс. 2009. № 12. С. 41-48.

2. Деришев Ю.В. Уголовное досудебное производство: концепция процедурного и функционально-правового построения : дис. ... д-ра юрид. наук. Омск, 2005. 437 с.

3. Ляхов Ю.А. Приоритеты уголовно-процессуального законодательства // Государство и право. 2010. № 8. С. 43-48. 
4. Концепция судебной реформы в Российской Федерации. М. : Республика, 1992. $111 \mathrm{c}$.

5. Багмет А.М., Цветков Ю.А. Сильное следствие и его противники // Lex Russica. 2015. № 4. С. 60-69.

6. Цветков Ю.А. Досудебное производство в ожидании современной доктрины // Уголовный процесс. 2015. № 5. С. 71-81.

7. Боруленков Ю.П. Призывы к ликвидации предварительного следствия не основаны на современных российских реалиях // Уголовное судопроизводство. 2016. № 1. C. $16-21$.

8. Поздняков М.Л. Каким не стать Следственному комитету к 2017 г. // Уголовное судопроизводство. 2014. № 1. С. 20-24.

9. Титаев К.Д., Шклярук М.С. Российский следователь: призвание, профессия, повседневность. М. : Норма, 2016. 192 с.

10. Зорькин В.Д. Пришли к согласию // Рос. газ. 2006. 6 сент., № 197.

11. Рамазанов И.Р. О следственных судьях и адвокатах // Уголовный процесс. 2015. № 5. C. 3 .

12. Головко Л.В. Реформирование следственных органов в России // Вестник московского университета. Сер. 11, Право. 2013. № 3. С. 43-55.

13. Цветков Ю.А. Роль процессуального контроля в повышении качества предварительного следствия // Уголовное судопроизводство. 2018. № 1. С. 34-41.

14. Цветков Ю.А. Кризис социально-правовой идентичности следователя и прокурора // Уголовное судопроизводство. 2014. № 1. С. 14-20.

15. Боруленков Ю.П. О полномочиях прокурора на стадии возбуждения уголовного дела // Библиотека криминалиста. 2014. № 1 (12). С. 33-39.

16. Воскобитова Л.А. Обвинение или обвинительный уклон? // Актуальные проблемы российского права. 2014. № 3 (40). С. 455-462.

17. Колоколов Н.А. Великое противостояние: следователь vs прокурор // Библиотека криминалиста. 2014. № 5 (16). С. 9-29.

18. Головко Л.В. Казахстан: десоветизация уголовного процесса. Статья 1: «Отказ от стадии возбуждения уголовного дела» // Уголовное судопроизводство. 2011. № 4. C. $10-13$.

19. Цветков Ю.А. «Улыбка без кота», или Что остается от предварительного следствия // Уголовное судопроизводство. 2016. № 2. С. 18-23.

20. Деришев Ю.В. Концепция уголовного досудебного производства в правовой доктрине современной России. Омск : Омск. акад. МВД России, 2004. 340 с.

21. Гуляев А.П. Концепция реформирования предварительного расследования преступления // Российский следователь. 2012. № 11. С. 2-4.

22. Деришев Ю.В. Стадия возбуждения уголовного дела - «реликт социалистической законности» // Российская юстиция. 2003. № 8. С. 34-36.

23. Маслов И.А., Новиков А.М. Нерешенные проблемы стадии возбуждения уголовного дела при рассмотрении сообщений о налоговых преступлениях // Уголовное право. 2011. № 5. С. 85-90.

24. Бастрыкин: следователи ищут доказательства вины, а должны - истину. URL: https://ria.ru/defense_safety/20140424/1005265794.html (дата обращения: 01.09.2018).

25. Волеводз А.Г. Упразднение стадии возбуждения уголовного дела: цена вопроса // Уголовный процесс. 2014. № 1. С. 80-83.

26. Лазарева В.А. Доследственная проверка // Уголовное судопроизводство. 2016. № 4. C. 11-16.

27. Зяблина М.В. К вопросу об исключении из российского уголовного процесса стадии возбуждения уголовного дела // Российская юстиция. 2017. № 7. С. 66-69.

28. Истина... И только истина! Пять бесед о судебно-правовой реформе. М. : Юрид. лит., 1990. 432 с. 
Derishev Yuri V., Omsk law Academy (Omsk, Russian Federation)

ABOUT MODERN NATIONAL CRIMINAL PROCEDURE SCIENCE GENERALLY AND ORGANIZATIONS OF THE INVESTIGATIVE DEVICE IN PARTICULAR

Keywords: criminal pre-judicial proceedings, organization and procedures of preliminary investigation, pre-investigation production, investigator, prosecutor, head of investigative body.

\section{DOI: $10.17223 / 22253513 / 31 / 7$}

The present article deals with selected aspects and problems of the current state of national science of penal procedure in relation to optimization of the organization of criminal pre-judicial proceedings.

On the basis of the critical analysis of separate positions about the place of the investigative apparatus in state mechanism the author states that procedural science cannot move beyond the established framework of pre-judicial proceedings and that neither legislators nor practical workers have a full picture of views on the specified questions.

The occurrence of a similar situation has become possible in the conditions when the state and science of penal procedure don't have a verified single (non-departmental) concept of procedural and organizational legal (functional) structure of criminal pre-judicial proceedings.

In this regard, the author of the article offers his vision of a sought concept relying on the research of Professor A. P. Gulyaev.

The stage of initiation of legal proceedings needs to be transformed to the police inquiry according to the experience of pre-revolutionary Russia and contemporary foreign countries. By its gnoseological, legal, axiological and historical genetic nature the investigative power is a derivative of judicial authority under the full coincidence of their purpose. Thus, in this connection a preliminary investigation is a function of justice, and the investigator must be regarded as its representative and be in a judicial office.

The prosecutor in pre-judicial proceedings shall have different roles. In the course of a preliminary investigation he is a prosecuting attorney deprived of supervising powers. During pre-investigation and summary proceedings he is a procedural head of criminal prosecution combining the function of prosecuting and supervision over legality of penal procedure and operational search activity.

Differentiation of functions in the proceedings on the merits of the case and of the judicial control of legality and validity of preliminary investigation is ensured by introducing a relatively independent investigative judge who performs an independent judicial and control function.

At the same time the preliminary investigation must be conducted only on the crimes (as a rule, grievous and extremely grievous ones) requiring a careful examination of the circumstances of a criminal event and its consequences with optimal simplification of pre-judicial preparations of the criminal case files about the crimes which don't require a preliminary investigation.

The author believes that the theoretical framework for the above compromise has always been a single paradigm, which is not only accepted and shared by the scientific community but unifies the majority of its members. In other words, within the scientific community there is a need for a compromise i.e. a more or less coherent vision of a theoretical concept and, in particular, of procedural and functional legal construction of criminal pre-judicial proceedings.

\section{References}

1. Smirnov, A.V. (2009) Sovremennye problemy sledstvennoy vlasti v Rossii [Modern problems of investigative power in Russia]. Ugolovnyy protsess. 12. pp. 41-48.

2. Derishev, Yu.V. (2005) Ugolovnoe dosudebnoe proizvodstvo: kontseptsiya protsedurnogo $i$ funktsional'no-pravovogo postroeniya [Criminal pre-trial proceedings: the concept of procedural and functional legal construction]. Law Dr. Diss. Omsk.

3. Lyakhov, Yu.A. (2010) Priorities in criminal - procedure law-making. Gosudarstvo $i$ pravo-State and Law. 8. pp. 43-48. (In Russian). 
4. Russian Federation. (1992) Kontseptsiya sudebnoy reformy v Rossiyskoy Federatsii [The Concept of Judicial Reform in the Russian Federation]. Moscow: Respublika.

5. Bagmet, A.M. \& Tsvetkov, Yu.A. (2015) Strong investigation and its opponents. Lex Russica. 4. pp. 60-69. (In Russian).

6. Tsvetkov, Yu.A. (2015) Dosudebnoe proizvodstvo v ozhidanii sovremennoy doktriny [Pretrial proceedings in anticipation of modern doctrine]. Ugolovnyy protsess. 5. pp. 71-81.

7. Borulenkov, Yu.P. (2016) Calls for Elimination of Preliminary Investigations are not Based on Today's Russian Realities. Ugolovnoe sudoproizvodstvo - Criminal Judicial Proceeding. 1. pp. 16-21. (In Russian).

8. Pozdnyakov, M.L. (2014) What the Investigative Committee of Russia should not become by 2017. Ugolovnoe sudoproizvodstvo - Criminal Judicial Proceeding. 1. pp. 20-24. (In Russian).

9. Titaev, K.D. \& Shklyaruk, M.S. (2016) Rossiyskiy sledovatel': prizvanie, professiya, povsednevnost' [Russian investigator: vocation, profession, every day life ]. Moscow: Norma.

10. Zorkin, V.D. (2006) Prishli k soglasiyu [On agreement]. Rossiskaya gazeta. 6th September.

11. Ramazanov, I.R. (2015) O sledstvennykh sud'yakh i advokatakh [About investigative judges and lawyers]. Ugolovnyy protsess. 5. pp. 3.

12. Golovko, L.V. (2013) Reformirovanie sledstvennykh organov v Rossii [Reforming Russian investigative bodies]. Vestnik moskovskogo universiteta. Ser. 11. Pravo. 3. pp. 43-55.

13. Tsvetkov, Yu.A. (2018) The Role of Procedural Control in Increasing the Quality of Preliminary Investigation. Ugolovnoe sudoproizvodstvo - Criminal Judicial Proceeding. 1. pp. 34-41. (In Russian).

14. Tsvetkov, Yu.A. (2014) Crisis of the social and legal identity of investigator and attorney. Ugolovnoe sudoproizvodstvo - Criminal Judicial Proceeding. 1. pp. 14-20. (In Russian).

15. Borulenkov, Yu.P. (2014) O polnomochiyakh prokurora na stadii vozbuzhdeniya ugolovnogo dela [On the powers of the prosecutor at the stage of initiating a criminal case]. Biblioteka kriminalista. 1(12). pp. 33-39.

16. Voskobitova, L.A. (2014) Obvinenie ili obvinitel'nyy uklon? [Charge or prosecutorial bias?]. Aktual'nye problemy rossiyskogo prava - Actual Problems of Russian Law. 3(40). pp. 455-462. (In Russian). DOI: 10.7256/1994-1471.2014.3.11105

17. Kolokolov, N.A. (2014) Velikoe protivostoyanie: sledovatel' vs prokuror [Great standoff: investigator vs prosecutor]. Biblioteka kriminalista. 5(16). pp. 9-29.

18. Golovko, L.V. (2011) Kazakhstan: desovetizatsiya ugolovnogo protsessa. Stat'ya 1: "Otkaz ot stadii vozbuzhdeniya ugolovnogo dela" [Kazakhstan: criminal process desovetisation. Article 1: "Refusal from the stage of initiating a criminal case"]. Ugolovnoe sudoproizvodstvo - Criminal Judicial Proceeding. 4. pp. 10-13.

19. Tsvetkov, Yu.A. (2016) A Grin Without a Cat, or What will remain of the Preliminary Investigation? Ugolovnoe sudoproizvodstvo - Criminal Judicial Proceeding. 2. pp. 18-23. (In Russian).

20. Derishev, Yu.V. (2004) Kontseptsiya ugolovnogo dosudebnogo proizvodstva $v$ pravovoy doktrine sovremennoy Rossii [The concept of criminal pre-trial proceedings in the legal doctrine of modern Russia]. Omsk: Omsk Acadedmy of Russian Ministry of Internal Affairs.

21. Gulyaev, A.P. (2012) Reformation conception of preliminary investigation. Rossiyskiy sledovatel' - Russian Investigator. 11. pp. 2-4. (In Russian).

22. Derishev, Yu.V. (2003) Stadiya vozbuzhdeniya ugolovnogo dela - "relikt sotsialisticheskoy zakonnosti" [The stage of initiation of a criminal case - "a relic of socialist legality"]. Rossiyskaya yustitsiya - Russian Justitia. 8. pp. 34-36.

23. Maslov, I.A. \& Novikov, A.M. (2011) The problems of the stage of institution of a criminal case during consideration of reports on tax crimes. Ugolovnoe pravo. 5. pp. 85-90. (In Russian). 
24. Ria.ru. (2014) Bastrykin: sledovateli ishchut dokazatel'stva viny, a dolzhny - istinu [Bastrykin: investigators are looking for evidence of guilt, but they should look for the truth]. [Online] Available from: https://ria.ru/defense_safety/20140424/1005265794.html. (Accessed: 1st September 2018).

25. Volevodz, A.G. (2014) Uprazdnenie stadii vozbuzhdeniya ugolovnogo dela: tsena voprosa [The abolition of the stage of initiation of a criminal case: the price paid]. Ugolovnyy protsess. 1. pp. 80-83.

26. Lazareva, V.A. (2016) Pre-Investigation Check. Ugolovnoe sudoproizvodstvo Criminal Judicial Proceeding. 4. pp. 11-16. (In Russian).

27. Zyablina, M.V. (2017) The issue of exclusion of the Russian criminal trial stages of a criminal case. Rossiyskaya yustitsiya - Russian Justitia. 7. pp. 66-69. (In Russian).

28. Anon. (1990) Istina... I tol'ko istina! Pyat' besed o sudebno-pravovoy reforme [Truth ... And only truth! Five conversations about judicial reform]. Moscow: Yuridicheskaya literatura. 